\title{
Reproductive biology and diet of Liophis poecilogyrus poecilogyrus (Serpentes, Colubridae) from southeastern Brazil
}

\author{
Roberta R. Pinto and Ronaldo Fernandes \\ Departamento de Vertebrados, Museu Nacional, Universidade Federal do Rio de Janeiro, Quinta da Boa Vista, Rio de \\ Janeiro, RJ, 20940-040, Brazil. E-mails: robertarich@mn.ufrj.br; ronnie@acd.ufrj.br.
}

\begin{abstract}
Reproductive biology and diet of Liophis poecilogyrus poecilogyrus (Serpentes, Colubridae) from southeastern Brazil. We describe the reproductive pattern and the diet of Liophis poecilogyrus poecilogyrus based on examination of museum specimens. The snake has an aseasonal reproductive pattern, suggesting multiple clutches during a year. Females are larger than males when sexual maturity is reached. Clutch size ranges from six to 15 eggs. The diet of Liophis poecilogyrus poecilogyrus is composed of anurans, and there are no a foraging decrease during the clutching season.
\end{abstract}

Keywords: Serpentes, Colubridae, Liophis poecilogyrus poecilogyrus, reproductive biology, diet, southeastern Brazil.

\section{Introduction}

The colubrid snake Liophis poecilogyrus (Wied-Neuwied, 1825) (Xenodontinae, Xenodontini) is broadly distributed over South America. Four subspecies are currently recognized, being the nominal restricted to the Atlantic Forest (Dixon and Markezich 1992) of Southeastern Brazil, where is rather common. Few studies concern the biology of Liophis poecilogyrus. Vitt (1983) compared reproduction and diet of $L$. poecilogyrus with other species of the same tribe, mostly in the

Received 5 March 2004.

Accepted 9 June 2004.

Distributed 30 September 2004. genus Liophis. Maciel (2001) described the reproductive biology and diet of a population of L. poecilogyrus from the Brazilian state of Rio Grande do Sul. Taxonomy of L. poecilogyrus, as currently recognized, is problematic (Daniel S. Fernandes pers. com.), but L. p. poecilogyrus is thought to be the most differentiated subspecies (Dixon and Markezich 1992). Despite being a snake well represented in scientific collections, there are no detailed data available about its reproductive biology and diet. The objective of this study was to evaluate several aspects of the biology of $L . p$. poecilogyrus, such as reproductive cycle pattern, size at sexual maturity, sexual dimorphism, female reproductive investment, and diet, based on preserved specimens in scientific collections. 


\section{Material and Methods}

We examined 142 specimens (Appendix I) of Liophis poecilogyrus poecilogyrus deposited in the herpetological collections of the Museu Nacional, Universidade Federal do Rio de Janeiro, Rio de Janeiro (MNRJ) and the Instituto Butantan, São Paulo (IB), of which 75 were females and 67 were males. These specimens were collected between 1913 and 2001. For each specimen, we made an incision in the abdomen and, when possible, we recorded: 1) diameter of the largest follicle or egg in the oviduct - measured with a dial caliper $(\mathrm{mm}) ; 2$ ) number of eggs; 3 ) degree of maturity in males; 4) snout-vent length (SVL) and tail length (TL) - measured with a flexible ruler ( $\mathrm{mm})$, and 5) presence of prey items in the stomach, noting, when possible, the direction of ingestion of the items. We considered as mature males with highly convoluted epididymides indicating the presence of sperm (Shine 1982) and as adult females those with follicles with a diameter larger than $3 \mathrm{~mm}$ (approximately half of the diameter of the smallest egg). Prey items were identified to the species level when possible and were analyzed by occurrence number (number of items per stomach) and recurrence (number of snakes that ingested each item).

ANOVAs and linear regression analyses were performed with the software Statistica for Windows version 5.1 (Statsoft 1997). The significance index was established as 0.05. Levene and Kolmogorov-Smirnov's tests were used to test the analysis of variance assumptions of homoscedasticity and normality, respectively.

\section{Results}

We found females with vitellogenic follicles in secondary development during the entire year (Figure 1). Clutch size of 16 females varied from 6 to $15(\bar{x}=8.25, S D=2.3)$. December was the month in which we found the highest proportion of females with eggs (4 individuals, representing $44.4 \%$ of the mature females of that month).

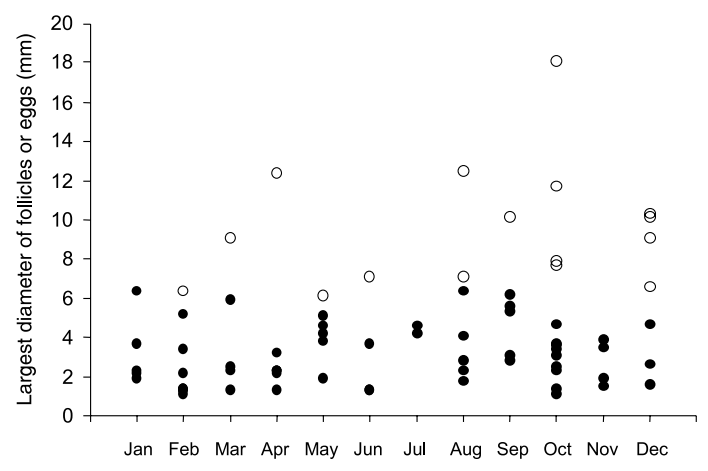

Figure 1 - Seasonal variation in the larger diameter of the follicles $(\bullet)$ or eggs (o) of all analyzed females Liophis poecilogyrus poecilogyrus.

We did not find a significant correlation neither between female SVL and number of eggs or between the diameter of the eggs and the female SVL. We found females with eggs in the oviduct and fully developed follicles, indicating multiple clutches in the same year.

Total length of mature males (SVL+TL) ranged from 447 to $864 \mathrm{~mm}(\overline{\mathrm{x}}=675.8, \mathrm{SD}=98$, $\mathrm{N}=48)$. Total length of mature females ranged from 604 to $1121 \mathrm{~mm}(\overline{\mathrm{x}}=840.7, \mathrm{SD}=110$, $\mathrm{N}=35)$. Females were larger in total length than males $\left(\mathrm{F}_{1,78}=53.7, \mathrm{p}=0.000001\right)$.

We found stomach items in $10(7.04 \%)$ of the analysed specimens (including one pregnant female), with a total of 15 items. Stomach contents consisted exclusively of anurans, mainly from the families Bufonidae and Hylidae, and we were able to determine the direction of ingestion in five prey items (Table 1).

\section{Discussion}

Sexual size dimorphism found in Liophis poecilogyrus poecilogyrus is a common feature along colubrids (Shine 1978, 1994). Usually, the larger body length of females increases fitness as larger specimens can have a higher fecundity (Shine 1994). However, we did not find a significant correlation between female size and 
Table 1 - Prey items found in stomach contents of Liophis poecilogyrus poecilogyrus. N1, occurrence number of each item; P1, percentage for the occurrence number of each item; N2, number of snakes that contained each item (the total number was inferior to number of items because some specimens presented more than one prey in their stomach); P2, percentage for the number of snakes that contained each item; P3, percentage for the occurrence number for each family.

\begin{tabular}{|c|c|c|c|c|c|c|}
\hline Prey Item & N1 & P1 & $\mathbf{N 2}$ & $\mathbf{P 2}$ & $\mathbf{P 3}$ & Direction of ingestion \\
\hline LEPTODACTYLIDAE & & & & & 26.7 & \\
\hline Thoropa miliaris & 2 & 13.3 & 2 & 20 & & $\begin{array}{l}\text { anterior-posterior } \\
\text { posterior-anterior }\end{array}$ \\
\hline Leptodactylus ocellatus & 1 & 6.7 & 1 & 10 & & anterior-posterior \\
\hline Indeterminate & 1 & 6.7 & 1 & 10 & & ? \\
\hline BUFONIDAE & & & & & 33.3 & \\
\hline Bufo crucifer & 2 & 13.3 & 2 & 20 & & posterior-anterior \\
\hline Bufo sp. (gr. crucifer) & 1 & 6.7 & 1 & 10 & & posterior-anterior \\
\hline Indeterminate & 2 & 13.3 & 2 & 20 & & $?$ \\
\hline HYLIDAE & & & & & 33.3 & \\
\hline Indeterminate & 5 & 33.3 & 3 & 30 & & $?$ \\
\hline Indeterminate Anura & 1 & 6.7 & 1 & 10 & 6.7 & $?$ \\
\hline TOTAL & 15 & 100 & 10 & & 100 & \\
\hline
\end{tabular}

number or size of eggs of Liophis p. poecilogyrus. We believe that the small number of females with eggs (16) may have precluded the finding of a more subtle relationship between the variables.

The presence of well developed vitelogenic follicles in Liophis p. poecilogyrus during the entire year suggests a continuous reproductive pattern, as found in other species of the tribe Xenodontini (Jordão 1996, Marques 1996). According to some authors (Vitt and Vangilder 1983, Seigel and Ford 1987), the type of diet and thus its seasonal availability may influence timing of reproductive cycles. Liophis $p$. poecilogyrus feeds primarily on anurans from the families Bufonidae and Hylidae, amphibians that are common over the distribution range of this snake (Heyer et al. 1990).

Vitt (1983) found a reduction in the number of females with follicles between the months of February and June among a sample of Liophis poecilogyrus schotti from the Caatinga. We could not find any decline in the number of females with follicles of L. p. poecilogyrus in June and July. As those months are characterized by the lowest annual temperature average in Southeastern Brazil (Nimer 1979), we would expect a reduction of the metabolism (Lillywhite 1987) and therefore a reduction of the allocation of energy to reproduction. Maciel (2001) found a seasonal reproductive pattern to the populations of L. p. sublineatus in Rio Grande do Sul. It is possible that the steep climatic variation of that state is responsible for the seasonal reproductive strategy discovered by Maciel (2001). Apparently, environmental factors are strong determinants of the reproductive cycle patterns in this species.

The continuous reproductive pattern of $L . p$. poecilogyrus and the fact that at least some females possess both eggs and well developed follicles suggest the existence of multiple 
clutches. Such phenomenon was also suggested by Maciel (2001) for populations of Liophis $p$. sublineatus in Rio Grande do Sul, although it was not found by Vitt (1983), while studying $L$. p. schotti in the Caatinga. Such results suggest that the species may use different reproductive tactics in different environments. On the other hand, multiple clutches appear to be a common feature in many Xenodontini (Jordão 1996, Marques 1996, Pizzatto 2003).

The size of the smallest female with vitelogenic follicles was greater than the size of the smallest adult male. Frequently, this result is interpreted as an indication that the sexual maturity occurs later in females (Shine 1978, Vitt 1983). Later maturity in females may represent a tradeoff in which sexual maturity is delayed so that larger clutches of larger eggs can be produced. Females invest in a larger size, as size confers fecundity. Furthermore, females tend to spare energy as reproduction is much more costly to them in relation to the males (Shine 1994). However, Maciel (2001) found a higher growth rate among the females of L. p. sublineatus in Rio Grande do Sul. If Maciel's (2001) finding is also valid to the snake studied herein, we could not affirm that the females mature after the males, but only that maturity is achieved with a larger size in this gender.

We found a high number of hylids (Table 1) in the stomachs of L. p. poecilogyrus, which is in agreement with previous studies of this species (Vitt 1983, Michaud and Dixon 1989, Maciel 2001, Jorge da Silva et al. 2003). Although species of the family Hylidae are frequently mentioned as arboreal, individuals of this family can use several layers of the vegetation (Cardoso et al. 1989, Pombal 1997, Abrunhosa 2001, Bertoluci and Rodrigues 2002, Prado 2002). Thus, it is likely that L. p. poecilogyrus may capture hylids in certain occasions, such as during vocalization and egg deposition, when some species are close to the ground or in water, locations where this snake is usually captured (pers. obs.).

We found that, in $60 \%$ of the cases, L. p. poecilogyrus swallowed prey in the posterioranterior direction, unlike the results by Maciel (2001), where in $80 \%$ of the cases the prey were ingested in the anterior-posterior direction. A possible explanation to this difference is that the southern population feeds predominantly on leptodactylids. Frogs of this family do not possess paratoid glands, as do toads of the family Bufonidae, which, in all examined specimens, are always ingested in the posterior-anterior direction by L. p. poecilogyrus. We speculate that L. p. poecilogyrus may avoid the early ingestion of the prey paratoid glands, allowing that they be squeezed in the initial stages of the intake and releasing a parcel of the toxin outside the snake's mouth.

A pregnant female was found with prey items in the stomach. A similar result was found in a population of Liophis poecilogyrus in Southern Brazil (Maciel 2001), suggesting that females of L. p. poecilogyrus do not reduce or stop feeding during the clutching period.

\section{Acknowledgments}

We are grateful to Francisco L. Franco (IB) for the access and loan of the specimens and José P. Pombal Jr. (MNRJ) for identification of stomach items. The manuscript was benefited by the critical view of Daniel S. Fernandes, Otavio A. V. Marques, and José P. Pombal Jr.. We thank Fundação Carlos Chagas Filho de Amparo à Pesquisa do Estado do Rio de Janeiro (FAPERJ) and the Conselho Nacional de Desenvolvimento Científico e Tecnológico ( $\mathrm{CNPq}$ ) for the financial support.

\section{References}

Abrunhosa, P. A. 2001. Partilha de recursos associados à reprodução de uma comunidade de anfíbios anuros em uma poça temporária do Sudeste do Brasil. Unpublished M.Sc. Dissertation. Museu Nacional, Universidade Federal do Rio de Janeiro, Brazil.

Bertoluci, J. and M. T. Rodrigues. 2002. Utilização de hábitats reprodutivos e micro-hábitats de vocalização 
em uma taxocenose de anuros (Amphibia) da Mata Atlântica do sudeste do Brasil. Papéis Avulsos de Zoologia, São Paulo 42: 287-297.

Cardoso, A. J., G. V. Andrade and C. F. B. Haddad. 1989. Distribuição espacial em comunidades de anfíbios (Anura) no Sudeste do Brasil. Revista Brasileira de Biologia 49: 241-249.

Dixon, J. R. and A. L. Markezich, 1992. Taxonomy and geographic variation of Liophis poecilogyrus (Wied) from South America (Serpentes: Colubridae). The Texas Journal of Science 44: 131-166.

Heyer, W. R., A. S. Rand, C. A. G. Cruz, O. L. Peixoto, and C. E. Nelson. 1990. Frogs of Boracéia. Arquivos de Zoologia, São Paulo 31: 231-410.

Jordão, R. 1996. Estudo comparativo da alimentação e da reprodução de Waglerophis merremii e Xenodon neuwiedii (Serpentes: Colubridae). Unpublished M.Sc. Dissertation. Universidade de São Paulo, Brazil.

Jorge da Silva, N. Jr., I. F. Souza and H. L. R. Silva. 2003. Diet of Liophis poecilogyrus. Herpetological Review 34: 69-70.

Lillywhite, H. B. 1987. Temperature, energetics, and physiological ecology. Pp. $422-477$ in R. A Seigel, R. A. Collins and S. S. Novak (eds.), Snakes - ecology and evolutionary biology. New York. MacMillan Publications.

Maciel, A. P. 2001. Ecologia e história natural da cobrado-capim, Liophis poecilogyrus (Serpentes: Colubridae), no Litoral Norte do Rio Grande do Sul, Brasil. Unpublished M.Sc. Dissertation. Universidade Federal do Rio Grande do Sul, Brazil.

Marques, O. A. V. 1996. Biologia reprodutiva da cobracoral Erythrolamprus aesculapii Linnaeus (Colubridae), no Sudeste do Brasil. Revista Brasileira de Zoologia 13: 747-753.

Michaud, E. J. and J. R. Dixon. 1989. Prey items of 20 species of the neotropical colubrid snake genus
Liophis. Herpetological Review 20: 39-41.

Nimer, E. 1979. Climatologia do Brasil. Rio de Janeiro. Fundação Instituto Brasileiro de Geografia e Estatística. $421 \mathrm{pp}$.

Pizzatto, L. P. 2003. Reprodução de Liophis miliaris (Serpentes: Colubridae) no Brasil: influência histórica e variações geográficas. Unpublished M.Sc. Dissertation. Universidade Estadual de Campinas, Brazil.

Pombal, J. P. Jr. 1997. Distribuição espacial e temporal de anuros (Amphibia) em uma poça permanente na Serra de Paranapiacaba, Sudeste do Brasil. Revista Brasileira de Biologia 57: 583-594.

Prado, G. M. 2002. Distribuição espacial e temporal dos anfíbios anuros em um brejo da reserva biológica de Duas Bocas, Espírito Santo, Sudeste do Brasil. Unpublished M.Sc. Dissertation. Museu Nacional, Universidade Federal do Rio de Janeiro, Brazil.

Seigel, R. A. and N. B. Ford. 1987. Reproductive ecology. Pp. 210-252 in R. A. Seigel, R. A. Collins and S. S. Novak (eds.), Snakes - ecology and evolutionary biology. New York. MacMillan Publications.

Shine, R. 1978. Sexual size dimorphism and male combat in snakes. Oecologia 33: 269-277.

Shine, R. 1982. Ecology of the Australian elapid snake Echiopsis curta. Journal of Herpetology 16: 388-393.

Shine, R. 1994. Sexual dimorphism in snakes revisited. Copeia 1994: 326-356.

Statsoft, Inc. 1997. Statistica for Windows version 5.1. Tulsa.

Vitt, L. J. 1983. Ecology of an anuran-eating guild of terrestrial tropical snakes. Herpetologica 39: 52-66.

Vitt, L. J. and L. D. Vangilder. 1983. Ecology of a snake community in northeastern Brazil. Amphibia-Reptilia 4: 273-296. 


\section{Appendix I}

Material examined from herpetological collections Museu Nacional (MNRJ) and Instituto Butantan (IB)

Espírito Santo: Águia Branca: IB-29004; Araguaia: IB-20363, IB-28471, IB-28842, IB-50671; Domingos Martins: IB-49695, IB-53292, IB-54988; Guarapari: MNRJ-4844; Guaçuí: IB-49972, IB-51653, IB-51712; Itá: IB-7647, IB-7844, IB-9240; Santa Leopoldina: IB-1205, IB-28051; Santa Teresa: MNRJ-8018, MNRJ-1271, MNRJ-1270, MNRJ-812, MNRJ-817, MNRJ-813; São Gabriel da Palha: IB-49644, IB-51200, IB-52264, IB-52266; São Mateus: IB-49090; Vitória: IB-51858, IB-51859.

Minas Gerais: Coronel Fabriciano: IB-22961, IB-22988, IB-23013; Juiz de Fora: IB-15456, IB-27953, IB-27952, IB-29151, IB-29428, IB-45827, IB-21813, IB-31434, IB-18928; Laranjal: IB-50048; Mariana: IB-7919; Penha Longa: IB-6592, IB-6639; Ponte Nova: IB-4467; Santos Dumont: IB-31493; São Sebastião da Estrela: IB-8117; Sereno: IB-12111, IB-18833, IB-18832; Sossego: IB-13205.

Rio de Janeiro: Campos: MNRJ-810; Caxias: MNRJ-793, MNRJ-790, MNRJ-7547, MNRJ7543, MNRJ-7548, MNRJ-7550, MNRJ-7549, MNRJ-2812, MNRJ-2862, MNRJ-2815, MNRJ2800, MNRJ-2871, MNRJ-2743, MNRJ-2814, MNRJ-2869, MNRJ-2750, MNRJ-2640, MNRJ2801, MNRJ-2732, MNRJ-2736; Conservatória: IB-6864; Costa Barros: MNRJ-7627; Ilha Grande: MNRJ-9780, MNRJ-7572; Itaboraí: MNRJ-8724; Itatiaia: MNRJ-7694, MNRJ-7397, MNRJ7355, MNRJ-7522, MNRJ-7558, MNRJ-2777; Mendes: MNRJ-7628; Miguel Pereira: IB-18442; Niterói: MNRJ-4690, MNRJ-7524; Nova Iguaçu: MNRJ-7626, MNRJ-7621, MNRJ-7569, MNRJ7568, MNRJ-2907; Palmeiras: MNRJ-806; Parati: IB-46619, IB-55148, IB-55149; Paulo de Frontin: MNRJ-6503; Pedra de Guaratiba: MNRJ-7630; Petrópolis: MNRJ-791, MNRJ-7610; Resende: IB-23130, IB-22769; Rio Bonito: MNRJ-7625; Rio Claro: IB-28614, IB-29952, IB-6397, IB-6395; Rio de Janeiro: MNRJ-8722, MNRJ-8721, MNRJ-8289, MNRJ-811, MNRJ-795, MNRJ7629, MNRJ-7618, MNRJ-7515, MNRJ-2843, MNRJ-2648, MNRJ-2649, MNRJ-7579, MNRJ2903, MNRJ-2904, MNRJ-4884; Santana: IB-6855; São Gonçalo: MNRJ-7574; Saquarema: MNRJ-7860, MNRJ-7859; Tanguá: MNRJ-8157; Trajano de Morais: IB-21518; Valença: MNRJ7054; Volta Redonda: IB-6637.

São Paulo: Bananal: IB-8331, IB-27133, IB-27783, IB-30157; Cruzeiro: IB-21015; São José do Barreiro: IB-8133, IB-56455; São Paulo: IB-7770, IB-27132; Queluz: IB-42550. 